\title{
Relative Lability of Trace Metals Complexed in Aquatic Humic Substances Using Ion-Exchanger Cellulose-Hyphan
}

\author{
Julio C. Rocha*, Ilda A.S. Toscano, and Arnaldo A. Cardoso \\ Departamento de Química Analítica, Instituto de Química de Araraquara- UNESP, \\ C.P. 355, 14800-900 Araraquara - SP, Brazil
}

Received: March 28, 1996

\begin{abstract}
Neste estudo as frações metálicas, complexadas por substâncias húmicas aquáticas (SH) foram caracterizadas como lábeis/inertes em função do $\mathrm{pH}$, tempo de complexação e concentração de SH. As SH foram extraídas por ultrafiltração e complexadas com íons metálicos bivalentes. Essas frações foram caracterizadas por processo de troca iônica utilizando resina celulósica Hyphan e procedimento em batelada. Os metais foram determinados por espectrometria de absorção atômica. Os resultados mostram diminuição dos coeficientes de distribuição $(\mathrm{Kd})$ na presença de SH e que a labilidade relativa das frações metálicas complexadas pelas SH é influenciada pelo tempo de complexação, pH e concentração de SH. Até cerca de 15 min, a troca iônica entre os metais complexados pela SHe a resina se comporta como reação de $2^{\underline{a}}$ ordem. Após esse período, o processo de troca é mais lento caracterizando uma cinética de $1^{\mathrm{a}}$ ordem. Os resultados permitem estabelecer a seguinte ordem de labilidade relativa para as frações metálicas complexadas por $\mathrm{SH}: \mathrm{Pb}>\mathrm{Mn}>\mathrm{Cd}$, $\mathrm{Ni}>\mathrm{Cu}$.
\end{abstract}

The purpose of this paper is to characterize the lability/inertness metal fractions complexed by aquatic humic substances (HS) in relation to $\mathrm{pH}$, complexation time, and HS concentration. HS were preconcentrated by ultrafiltration and complexed with bivalent metal ions. These fractions were characterized by ion exchange with the chelating collector cellulose Hyphan by applying batch procedure. The metals were determined by atomic absorption spectrometry. The results show that the distribution coefficients, $\mathrm{Kd}$, decreased with HS presence, and that the relative lability of metal fractions complexed by HS is dependent on variables such as $\mathrm{pH}$, complexation time, and HS concentration. Until c.a. $15 \mathrm{~min}$, the metal change between aquatic HS and ion exchanger occurs following a $2^{\text {nd }}$ order reaction. Afterwards, the remaining metal fraction in the HS reacts following a $1^{\text {st }}$ order reaction. For traces of metal ions bound to dissolved $\mathrm{HS}$, the lability orderPb $>\mathrm{Mn}>\mathrm{Cd}, \mathrm{Ni}>\mathrm{Cu}$ is revealed.

Keywords: aquatic humic substances, ion-exchange, metal complexation

\section{Introduction}

HS are a complex mixture of related macromolecules formed by the biological decomposition of plants in soils, and transported to natural waters by leaching. These macromolecules exhibit a great number of functional groups, particularly phenolic and carboxylic ${ }^{1,2}$. Metal-organic interactions, including complexation reactions of metal ions and HS, are becoming increasingly recognized as important factors in many natural systems ${ }^{3}$. The structure and chemical behavior of these funcionalities have been studied over the last decade. The high stability of metal fractions when complexed with biological or artificial ligand sources interfere directly in the transportation, accumulation and bioavailability of metals in the environment ${ }^{4}$. There is considerable evidence that the free ionic forms of metals like copper, lead, cadmium and aluminum are usually the forms most toxic to aquatic biota, and that complexation by HS reduces the toxicity of these metal ions ${ }^{5}$. The lability/inertness of metal ions complexed with 
HS, and the way they are transported under natural conditions, must be evaluated ${ }^{6}$.

The low species concentrations in complex matrices, where there is also a great number of interferents, have been the major problem in the development of analytical methods for the characterization of different chemical species in the environment, both qualitatively and quantitatively ${ }^{7}$.

Here, we describe how the chelating ion exchanger cellulose-Hyphan can be used as an effective collector for labile trace metals remaining in aquatic HS. Using an optimized batch procedure, the kinetics, degree of ion exchange reaction, and influence of transformation processes (ageing) can serve as parameters for the evaluation of metal lability in HS.

\section{Materials and Methods}

\section{Chemicals and reagents}

The multi-element solution of the metal and all acids and bases for the preparation of solutions and HS-isolation were highly pure. Deionized water from a Millipore MilliQ system was used.

\section{Ion-exchange resin}

The ion-exchanger used for the differentiation of labile/inert metal fractions was the resin of cellulose-based Hyphan (TM Riedel-de Haën AG), (1-(2-hydroxyfenylazo)-2-naftol) functional amino group, $\mathrm{C}_{6} \mathrm{H}_{3}(\mathrm{OH}) \mathrm{N}=\mathrm{NC}_{10} \mathrm{H}_{6} \mathrm{OH}$, with $\mathrm{Kd} \mid 10^{5}$ and an exchange capacity of $0.2-0.4 \mathrm{mmol} \mathrm{Cu}(\mathrm{II}) / \mathrm{g}$ of dry resin ${ }^{8}$.

\section{Humic substance extraction}

Humic-rich water was collected from an ecological reserve lake (Venner Moor) in Münster, Germany. After filtration through a $0.45 \mu \mathrm{m}$ membrane, $150 \mathrm{~L}$ of the sample was concentrated by ultrafiltration (UF) to $0.5 \mathrm{~L}$ (keeping the original $\mathrm{pH}$ of 4.5). A Millipore Pellicon system was used (tangential flow with a nominal molecular weight cut-off of 1000 Dalton, a filtering area of $0.42 \mathrm{~m}^{2}$, and a penetrating flow of $25 \mathrm{~mL} / \mathrm{min}$ ).

\section{Dissolved organic carbon - DOC}

The DOC value of the HS sample was determinated by oxidation to $\mathrm{CO}_{2}$ and measurement with an IR-analyzer (Shimadzu TOC 2000). The HS concentration was evaluated at $7 \mathrm{mg} / \mathrm{mL}$, due to a DOC concentration of $14 \mathrm{mg} / \mathrm{mL}^{9}$.

\section{Complexing capacity $(\mathrm{Cu}(\mathrm{II}))$ of $H S$}

The complexing capacity $(2.7 \mathrm{mmol} \mathrm{Cu}$ (II) per g DOC) of aquatic HS was determined by a copper(II) selective electrode (WTW Cu 500) ${ }^{10}$.

\section{Preparation of standardized HS solutions}

The HS standards were prepared from their concentrates by dilution to $1.0 \mathrm{mg} / \mathrm{mL}$. In order to remove the metals which occur naturally in the HS, $1 \mathrm{~g}$ (dry weight) of highly pure Hyphan resin was added and kept under agitation for $72 \mathrm{~h}$ at $\mathrm{pH}$ 9.0. After filtration, the $\mathrm{pH}$ was adjusted to 4.5 , and the HS standards were stocked in polyethylene bottles under refrigeration at $4{ }^{\circ} \mathrm{C}$.

\section{Metal spiking of $H S$}

The species formed between metal and humic substances (HS-M) were prepared by adding shares of multi-element solution of the metals. The $\mathrm{pH}$ was adjusted by the addition of $\mathrm{NaOH}$ or $\mathrm{HCl}$ and $1.0 \mathrm{~mL}$ of the corresponding buffer solution. The volumes were completed to $10.0 \mathrm{~mL}$ with highly pure water, and the solutions were stirred for $24 \mathrm{~h}$. The metal concentrations in the HS solutions were $\mathrm{Cd} 0.50, \mathrm{Ni} 2.0, \mathrm{Mn} 1.0, \mathrm{Cu} 2.0$, and $\mathrm{Pb}$ $5.0 \mathrm{mg} / \mathrm{L}$.

\section{Batch procedure ${ }^{11}$}

After the complexation equilibrium (HS-M) was guaranteed (24 h), $20 \mathrm{mg}$ Hyphan was added and stirred for $1 \mathrm{~h}$. The ion-exchanger was filtered through filter paper (20 mm diameter) previously cleaned with 2 mol/L $\mathrm{HCl}$. Paper and resin were transferred to small flasks and extracted for $1 \mathrm{~h}$ with $3.0 \mathrm{~mL}$ of $2 \mathrm{~mol} / \mathrm{L} \mathrm{HCl}$. After centrifugation (4000 rpm), the analytes contained in the extracts were determined by flame absorption atomic spectrometry (FAAS).

\section{Metal determinations by FAAS}

Trace metals concentrated in the eluates were directly determined by FAAS, according to the manufacturer's operating instructions (Spectrometer Varian-Intralab-AA 1475). For the calibration curves, synthetic metal standard solutions containing 0 to $5.0 \mu \mathrm{g} / \mathrm{mL}$ of each metal in $2 \mathrm{~mol} / \mathrm{L} \mathrm{HCl}$ were used.

\section{Results and Discussion}

\section{Distribution coefficient: effect of $p H$}

The efficient multi-element preconcentration by an ion exchange batch procedure requires collectors offering high distribution coefficients ${ }^{12}$, Kd, preferably of $>10^{4}$, calculated by the following equation:

$$
\mathrm{Kd}=\frac{\mathrm{C}_{\mathrm{col}}}{\mathrm{C}_{\mathrm{sol}}}(\mathrm{mL} / \mathrm{g})
$$

where $\mathrm{C}_{\mathrm{col}}=$ concentration of metals in the collector $(\mathrm{mg} / \mathrm{g})$, and $\mathrm{C}_{\mathrm{sol}}=$ concentration of metals in solution $(\mathrm{mg} / \mathrm{mL})$. 
The separation characteristics using the ion-exchanger cellulose-Hyphan as the collector for the reactive metal fractions by means of metal distribution coefficient, $\mathrm{Kd}$, in function of the $\mathrm{pH}$ is illustrated in Fig.1. Using batch procedure, these studies were carried out in the presence of $1 \mathrm{mg} / \mathrm{mL} \mathrm{HS}$ (HS-metal, equilibration for $24 \mathrm{~h}$ ) and without $\mathrm{HS}(\mathrm{NaCl} 1 \mathrm{~g} / \mathrm{L})$. In the absence of HS, the Hyphan collector exhibits $\mathrm{Kd}$ values as high as $10^{4}$ to $10^{5}(\mathrm{~mL} / \mathrm{g})$ for $\mathrm{Cd}$, $\mathrm{Pb}$, and $\mathrm{Cu}$ at a $\mathrm{pH}$ above 9.0, with probable uniform behavior for all metals. In contrast, in the presence of HS the enrichment of the metals on the collector phase decreases, and the Kd values are also lowered, on order of a factor of 100 in the $\mathrm{pH}$ range from 8 to 9 . Thus, in slightly alkaline solutions there is a large change of metals from aquatic HS to ion-exchanger.

In general, in the presence of $\mathrm{HS}$ and greater $\mathrm{pH}$ increases the apparent complex stability by decreasing the proton competition with metal ions for weakly acidic binding sites ${ }^{3}$. This behavior was not followed by the $\mathrm{Cu}$ fraction, in agreement with researches ${ }^{13}$ which showed that the complex stability for $\mathrm{Cu}-\mathrm{HS}$ decreases with increasing $\mathrm{pH}$.

\section{Lability order and kinetics studies}

Equilibrium fundamentals

The ion-exchangers of cellulose, particularly the Hyphan resin, present high distribution coefficients on the order of $10^{5}$ for some metal ions in salt solutions without $\mathrm{HS}^{14}$. According to previous studies ${ }^{15}$, cellulose-based ion-exchangers can be used as effective collectors for labile trace metals remaining in HS solution. Applying an optimized batch procedure, both the kinetics and the degree of

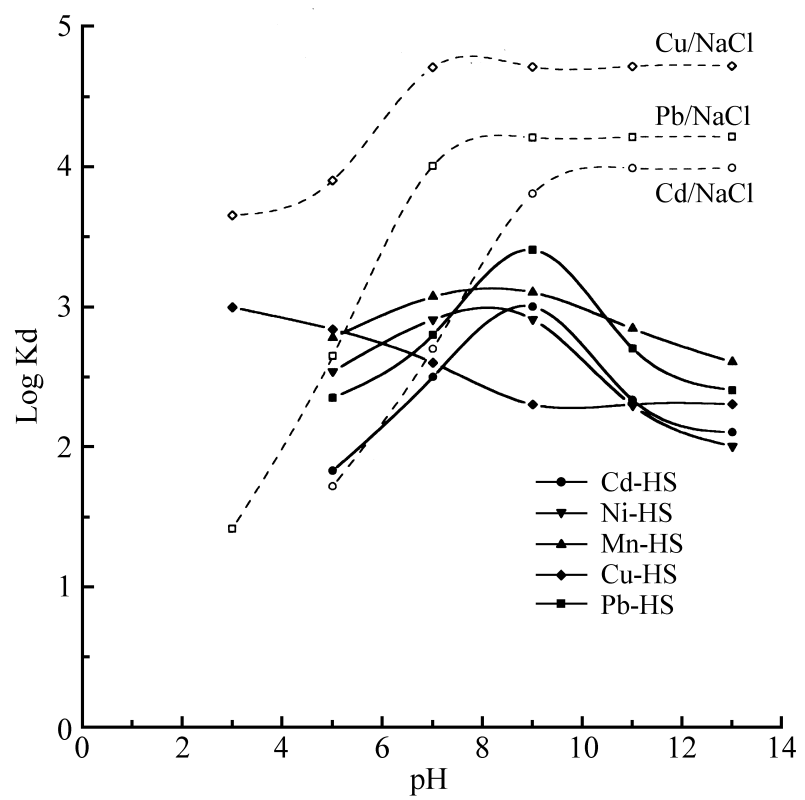

Figure 1. Metal distribution coefficient, $\mathrm{Kd}$, as a function of $\mathrm{pH}$ in the presence of salt $(\mathrm{NaCl} 1 \mathrm{~g} / \mathrm{L})$ and complexing $\mathrm{HS}(1 \mathrm{mg} / \mathrm{mL})$. Conditions: $24 \mathrm{~h}$ complexation time, $20 \mathrm{mg}$ Hyphan. metal removed from HS can be useful for characterizing the lability/inertness of heavy metals bound to HS. The exchange of metal ions between resins and labile macromolecular metal complexes like HS-M can be described by the following equilibrium:

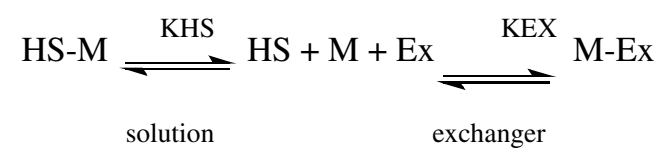

(charges omitted for simplicity)

where HS = humic substances, HS-M = species formed between metal, Ex= ion-exchanger, solid phase, and M-Ex= species formed between the metal and the collector.

Thus, the concentrations of species HS-M and M-Ex, governed by the equilibrium constants $\mathrm{K}_{\mathrm{HS}}$ and $\mathrm{K}_{\mathrm{Ex}}$, are shifted depending on important parameters like $\mathrm{pH}$, concentration of humic substances, complexation time, and the ratio of metal ions to HS.

\section{Lability order}

Table 1 shows the gradual separation of all metal ions complexed by $\mathrm{HS}$. The ion $\mathrm{Cu}$ reaches the exchange equilibrium before the other metal ions studied (about $15 \mathrm{~min}$ ). In general, a contact time of more than $60 \mathrm{~min}$ is required to attain the exchange equilibrium as given by Eq. 1. Afterwards, the efficiency separation does not change. The separation of metal ions from $\mathrm{HS}$ solutions, pre-conditioned for $24 \mathrm{~h}$, exhibits the typical lability order of $\mathrm{Pb}>\mathrm{Mn}>\mathrm{Cd}$, $\mathrm{Ni}>\mathrm{Cu}$. In particular, $\mathrm{Cu}$ is known to form strong HS complexes $^{16}$.

\section{Half-life time}

According to Table 1, if $120 \mathrm{~min}$ is considered the time in which the maximum concentration of metals is recovered by the resin, the separation kinetics has a half-life time $\left(\mathrm{t}_{1 / 2}\right)$ in the range of 1 to $5 \mathrm{~min}(\mathrm{Cu})$ and 5 to $15 \mathrm{~min}(\mathrm{~Pb}, \mathrm{Mn}$, $\mathrm{Cd}$, and $\mathrm{Ni}$ ).

\section{Reaction order}

Table 1. Recovery of metal ions pre-complexed by HS in function of contact time with the ion-exchanger cellulose-Hyphan. Conditions: $1 \mathrm{mg} / \mathrm{mL}$ HS, pH 9, 24 h complexation time, $20 \mathrm{mg}$ Hyphan.

\begin{tabular}{lccccccc}
\hline \multirow{2}{*}{ Metals } & \multicolumn{7}{c}{ Contact time (min)/recovery \% } \\
\cline { 2 - 8 } & 1 & 5 & 15 & 30 & 60 & 90 & 120 \\
\hline $\mathrm{Cd}$ & 15 & 21 & 32 & 45 & 56 & 56 & 56 \\
$\mathrm{Ni}$ & 13 & 26 & 37 & 41 & 54 & 54 & 54 \\
$\mathrm{Mn}$ & 24 & 35 & 49 & 52 & 68 & 68 & 68 \\
$\mathrm{Cu}$ & 18 & 32 & 46 & 46 & 46 & 46 & 46 \\
$\mathrm{~Pb}$ & 30 & 38 & 44 & 62 & 73 & 74 & 74 \\
\hline
\end{tabular}


The kinetics and the reaction order of this ion-exchange process can be derived from Fig. 2 (drawn from the data in Table 1), which exhibits the separation of the exchange labile metals $\mathrm{Pb}, \mathrm{Cd}$, and $\mathrm{Cu}$ (concentration $\mathrm{C}_{\mathrm{L}}$ ) plotted as a function of the contact time. Initially, $<15 \mathrm{~min}$, the labile metal fractions complexed by aquatic HS are separated relatively quickly. In this case, the metal exchange between HS solutions and the solid ion-exchanger occurs, following a $2^{\text {nd }}$ order reaction. Thus, the metal ions complexed with the HS react directly with the immobilized groups in the Hyphan. Later, the remaining metal fractions in the HS react following a slow $1^{\text {st }}$ order kinetics, compared to metal exchange by Hyphan from aqueous salt solutions $\left(t_{1 / 2}\right.$ of about $20 \mathrm{~s}^{14}$ ). The change of kinetic reaction occurs because the functional groups of the ion-exchanger react preferentially with metal fractions bound to the external sphere of HS. The rate of reaction decreases owing to the difficulty of the exchanger in interacting with metal ions complexed in less accessible sites in the inner sphere of HS.

\section{Effect of HS concentration on the distribution coefficients}

HS exhibit considerable complexing capacities for metal ions, due to the broad spectrum of potential binding sites. Thus, the aquatic HS concentration could be an important factor affecting the availability of metals in the aquatic environment. Accordingly, the distribution coefficients, $\mathrm{Kd}$, of metal ions on cellulose-Hyphan as a function of the HS concentration was determined by batch procedure. Figure 3 shows that all metals were better recovered in solutions with lower concentrations of HS. The complexation capacity increases at high humic concentra-

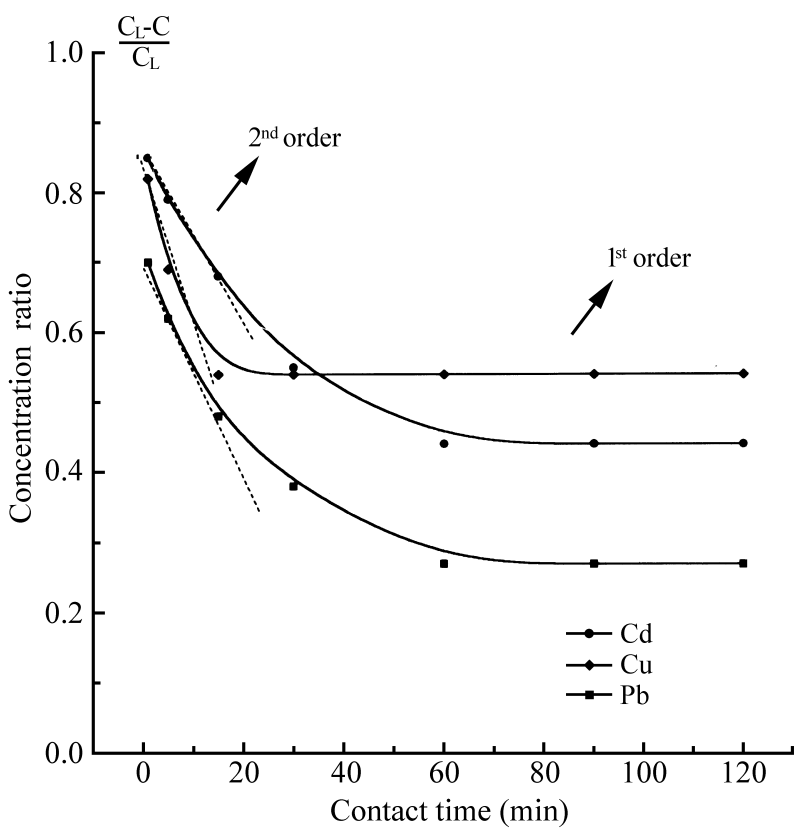

Figure 2. Separation of exchange-labile metal fractions (concentration $\mathrm{C}_{\mathrm{L}}$ ) from $\mathrm{HS}$ as a function of contact time. Conditions: see Table tions because there are more binding sites available for metal ion complexation, and the equilibrium is shifted towards the HS-M species. Thus, humic-rich waters are important as natural "buffers" for heavy metals in the environment. The influence of ageing processes

In the environment, the HS/metals interactions occur over a relatively long time (ageing process). Thus, this is an important factor that may affect the lability of metal fractions complexed by HS. The interaction time between aquatic humic substances and metal ions was studied. Fig-

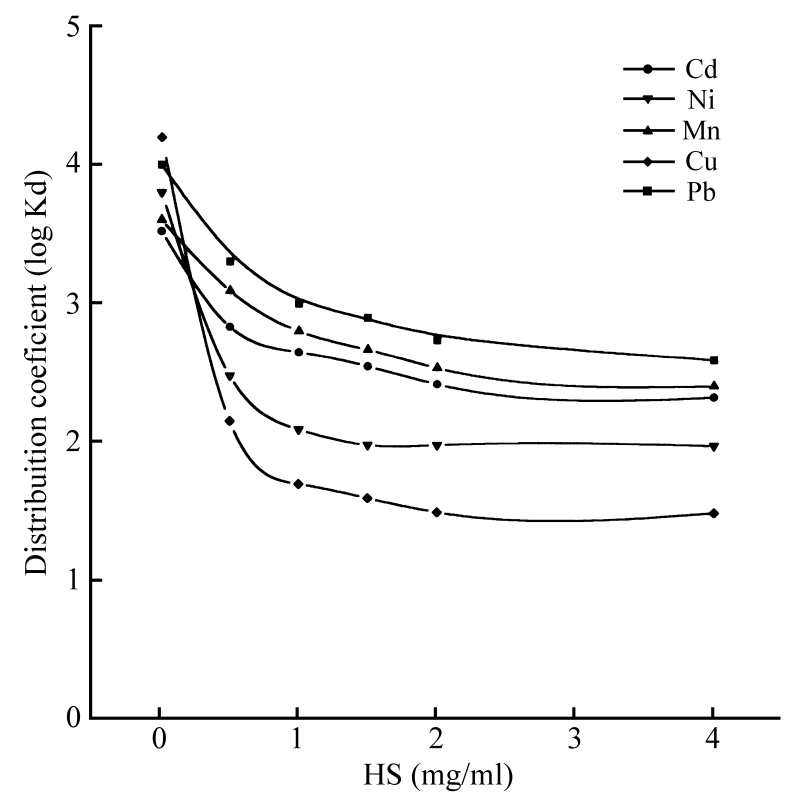

Figure 3. Metal distribution coefficients as a function of HS concentration. Conditions: $\mathrm{pH}$ 9, 24 h complexation time, $20 \mathrm{mg}$ Hyphan.

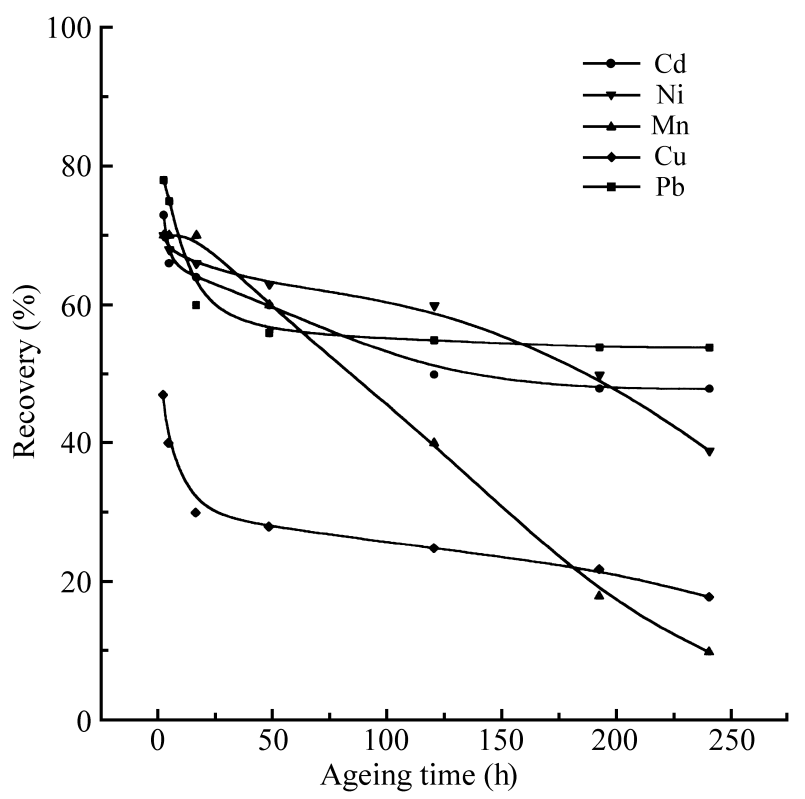

Figure 4. Influence of complexing time (ageing) on the lability of metals. Conditions: $1 \mathrm{mg} / \mathrm{mL}$ HS, pH 9, $20 \mathrm{mg}$ Hyphan. 
ure 4 shows that if the complexation time is increased, the lability of the metal fractions bound in aquatic HS decreases. This behavior is not the same for all metals. For instance, the manganese ion shows a remarkable decrease in lability, from $70 \%$ of recovery at $0.1 \mathrm{~h}$ to $10 \%$ after 10 days. In general, metals complexed with the most external groups of the HS macromolecule react preferentially with the functional groups of the resin. Consequently, the metal remains complexed for a long time, probably due to the transformation process and inner rearrangements. As time increases, less accessible binding sites of HS may be occupied, and a change of metal ions from weaker to stronger binding sites may take place ${ }^{17}$.

\section{Conclusions}

The present study demonstrates that the distribution coefficients, $\mathrm{Kd}$, of metal ions are strongly influenced by $\mathrm{pH}$ and HS concentration. The influence of contact time between the ion-exchanger and the metal-HS solution characterizes, at first, a $2^{\text {nd }}$ order reaction with a half-life $\left(\mathrm{t}_{1 / 2}\right)$ of 1 to $5 \mathrm{~min}$ for $\mathrm{Cu}$ ion and 5 and $15 \mathrm{~min}$ for $\mathrm{Pb}, \mathrm{Mn}, \mathrm{Cd}$, and $\mathrm{Ni}$. Another important factor that influences the lability of metal fractions bound to aquatic HS is the ageing process. This transformation process showed a gradual decrease of the overall lability of metal ions in dissolved HS. This behavior is probably due to slow metal exchange processes caused by an inner rearrangement in the binding sites within the HS molecules. Thus, it can be concluded that accumulation, transportation, hydrogeochemical cycles, and bioavailability of trace metals in natural waters frequently depend on the lability/inertness of metals bound to humic substances.

\section{Acknowledgments}

We are grateful Drs. Peter Burba and Dieter Klockow of the Institut für Spektrochemic und Angewandte Spektroskopie - ISAS - Dortmund, Germany for the valuable information. This work was supported by $\mathrm{CNPq}$, FAPESP and FUNDUNESP.

\section{References}

1. Leenheer, J.A. In Environmental Chemistry of Lakes and Reservoirs; Baker, L.A., Ed.; ACS Symposium Series 237; American Chemical Society: Washington, DC, 1994; p 165.
2. Förstner, U.; Ahlf, W.; Calmano, W.; Kersten, M.; Schoer, J. In Metal Speciation in the Environment; Broekaert, J.A.C.; Güçer, S.; Adams, F., Eds.; NATO ASI Series, Vol. 23; Springer-Verlag, Berlin, 1990; p 71.

3. Rate, A.W.; McLaren, R.G. Environ. Sci. Technol. 1993, 27, 1408.

4. Swift, R. In Humic Substances II; Hayes, M.H.B.; MacCarthy, P.; Malcolm, R.; Swift, R., Eds.;John Wiley \& Sons, Chichester, UK, 1989, p. 450.

5. Henze, G. In Metal Speciation in the Environment, Broekaert, J.A.C.; Güçer, S.; Adams, F., Eds.; NATO ASI Series, Vol. 23; Springer-Verlag, Berlin, 1990, p. 391.

6. Buffle, J. In Complexation Reactions in Aquatic Systems: an Analytical Approach; Ellis Horwood, Chichester, UK, 1990, p 16.

7. Rottman, H.; Heumann, K.G. Anal. Chem. 1994, 66, 3709.

8. Burba, P.; Lieser, K.L. Z. Anal. Chem. 1977, 286, 191.

9. Senesi, N. In Organic Substances in Soil and Water: Natural Constituents and their Influences on Contaminant Behavior; Beck, A.J.; Jones, K.C.; Hayes, M.H.B.; Milgelgrin, U., Eds.; Royal Society of Chemistry: Cambridge, 1993, p 73.

10. Buffle, J. In Complexation Reactions in Aquatic Systems: an Analytical Approach; Ellis Horwood Lim., Chichester, UK, 1990, p 427.

11. Burba, P.; Rocha, J.C.; Schulte, A. Fresenius J. Anal. Chem. 1993, 346, 414.

12. Paterson, R. In An introdution to Ion Exchange; Heyden \& Son, London, 1970, p. 27.

13. Finger, W.; Klamberg, H. In Progress in Hydrogeochemistry; Mathess, G.; Frimmel, F.H.; Hirsch, P.; Schulz, H.D.; Usdowski, E., Eds.; Springer-Verlag, Berlin, 1992, p 65.

14. Burba, P.; Blödorn, W. Von Wasser 1992, 79, 9.

15. Rocha, J.C.; Toscano, I.A.S.; Burba, P. (Accepted for publication in Talanta 1996).

16. Barros, M.C.P.; Paula, J.R.; Rezende, M.O.O. Química Nova 1994, 17, 376.

17. Burba, P. Fresenius J. Anal. Chem. 1994, 348, 301.

FAPESP helped in meeting the publication costs of this article 
ure 4 shows that if the complexation time is increased, the lability of the metal fractions bound in aquatic HS decreases. This behavior is not the same for all metals. For instance, the manganese ion shows a remarkable decrease in lability, from $70 \%$ of recovery at $0.1 \mathrm{~h}$ to $10 \%$ after 10 days. In general, metals complexed with the most external groups of the HS macromolecule react preferentially with the functional groups of the resin. Consequently, the metal remains complexed for a long time, probably due to the transformation process and inner rearrangements. As time increases, less accessible binding sites of HS may be occupied, and a change of metal ions from weaker to stronger binding sites may take place ${ }^{17}$.

\section{Conclusions}

The present study demonstrates that the distribution coefficients, $\mathrm{Kd}$, of metal ions are strongly influenced by $\mathrm{pH}$ and HS concentration. The influence of contact time between the ion-exchanger and the metal-HS solution characterizes, at first, a $2^{\text {nd }}$ order reaction with a half-life $\left(\mathrm{t}_{1 / 2}\right)$ of 1 to $5 \mathrm{~min}$ for $\mathrm{Cu}$ ion and 5 and $15 \mathrm{~min}$ for $\mathrm{Pb}, \mathrm{Mn}, \mathrm{Cd}$, and $\mathrm{Ni}$. Another important factor that influences the lability of metal fractions bound to aquatic HS is the ageing process. This transformation process showed a gradual decrease of the overall lability of metal ions in dissolved HS. This behavior is probably due to slow metal exchange processes caused by an inner rearrangement in the binding sites within the HS molecules. Thus, it can be concluded that accumulation, transportation, hydrogeochemical cycles, and bioavailability of trace metals in natural waters frequently depend on the lability/inertness of metals bound to humic substances.

\section{Acknowledgments}

We are grateful Drs. Peter Burba and Dieter Klockow of the Institut für Spektrochemic und Angewandte Spektroskopie - ISAS - Dortmund, Germany for the valuable information. This work was supported by $\mathrm{CNPq}$, FAPESP and FUNDUNESP.

\section{References}

1. Leenheer, J.A. In Environmental Chemistry of Lakes and Reservoirs; Baker, L.A., Ed.; ACS Symposium Series 237; American Chemical Society: Washington, DC, 1994; p 165.
2. Förstner, U.; Ahlf, W.; Calmano, W.; Kersten, M.; Schoer, J. In Metal Speciation in the Environment; Broekaert, J.A.C.; Güçer, S.; Adams, F., Eds.; NATO ASI Series, Vol. 23; Springer-Verlag, Berlin, 1990; p 71.

3. Rate, A.W.; McLaren, R.G. Environ. Sci. Technol. 1993, 27, 1408.

4. Swift, R. In Humic Substances II; Hayes, M.H.B.; MacCarthy, P.; Malcolm, R.; Swift, R., Eds.;John Wiley \& Sons, Chichester, UK, 1989, p. 450.

5. Henze, G. In Metal Speciation in the Environment, Broekaert, J.A.C.; Güçer, S.; Adams, F., Eds.; NATO ASI Series, Vol. 23; Springer-Verlag, Berlin, 1990, p. 391.

6. Buffle, J. In Complexation Reactions in Aquatic Systems: an Analytical Approach; Ellis Horwood, Chichester, UK, 1990, p 16.

7. Rottman, H.; Heumann, K.G. Anal. Chem. 1994, 66, 3709.

8. Burba, P.; Lieser, K.L. Z. Anal. Chem. 1977, 286, 191.

9. Senesi, N. In Organic Substances in Soil and Water: Natural Constituents and their Influences on Contaminant Behavior; Beck, A.J.; Jones, K.C.; Hayes, M.H.B.; Milgelgrin, U., Eds.; Royal Society of Chemistry: Cambridge, 1993, p 73.

10. Buffle, J. In Complexation Reactions in Aquatic Systems: an Analytical Approach; Ellis Horwood Lim., Chichester, UK, 1990, p 427.

11. Burba, P.; Rocha, J.C.; Schulte, A. Fresenius J. Anal. Chem. 1993, 346, 414.

12. Paterson, R. In An introdution to Ion Exchange; Heyden \& Son, London, 1970, p. 27.

13. Finger, W.; Klamberg, H. In Progress in Hydrogeochemistry; Mathess, G.; Frimmel, F.H.; Hirsch, P.; Schulz, H.D.; Usdowski, E., Eds.; Springer-Verlag, Berlin, 1992, p 65.

14. Burba, P.; Blödorn, W. Von Wasser 1992, 79, 9.

15. Rocha, J.C.; Toscano, I.A.S.; Burba, P. (Accepted for publication in Talanta 1996).

16. Barros, M.C.P.; Paula, J.R.; Rezende, M.O.O. Química Nova 1994, 17, 376.

17. Burba, P. Fresenius J. Anal. Chem. 1994, 348, 301. FAPESP helped in meeting the publication costs of this article 